\title{
Tolerance in Cucumber to Cucurbit yellow stunting disorder virus
}

Sahar Eid, Yusuf Abou-Jawdah, Choaa El-Mohtar, and Hana Sobh, Department of Plant Sciences, Faculty of Agricultural and Food Sciences, American University of Beirut, Beirut, Lebanon; and Michael Havey, United States Department of Agriculture-Agricultural Research Service, Department of Horticulture, University of Wisconsin, Madison 53706

\begin{abstract}
Eid, S., Abou-Jawdah, Y., El-Mohtar, C., Sobh, H., and Havey, M. 2006. Tolerance in cucumber to Cucurbit yellow stunting disorder virus. Plant Dis. 90:645-649.

Cucurbit yellow stunting disorder virus (CYSDV), genus Crinivirus and family Closteroviridae, has emerged as a serious whitefly-transmitted virus of cucurbit crops, causing between 30 and $50 \%$ yield losses. Development of resistant cultivars represents an economically and environmentally sound approach to management of this disease. In all, 124 cucumber accessions were evaluated for reaction to CYSDV under high inoculum pressure over three growing seasons. Seven accessions showed delayed expression of symptoms, milder final symptoms, and lower percentages of infected plants compared with susceptible cucumbers. Although none of these accessions were immune to CYSDV, virus concentrations in the middle leaves of the tolerant accessions were significantly lower than those of susceptible accessions.
\end{abstract}

Additional keywords: germ plasm, resistance

Yellowing diseases of cucurbit crops (cucumber (Cucumis sativus L.), squash ( $\mathrm{Cu}$ curbita spp.), melon (Cucumis melo L.), and watermelon (Citrullus lanatus (Thunb.) Matsum. \& Nakai)) are caused by whiteflytransmitted viruses and incite severe economic losses worldwide $(17,23)$. Three distinct whitefly-transmitted cucurbit yellows viruses have been distinguished: Beet pseudo yellows virus (BPYV) (7), Lettuce infectious yellows virus $(4,9)$, and Cucurbit yellow stunting disorder virus (CYSDV) (11). CYSDV first was identified in the United Arab Emirates in the 1990s (11) and since has been reported in Syria, Turkey, Jordan, Egypt, and Israel (8). CYSDV has spread throughout the Mediterranean basin, where it was recognized as a rapidly emerging and economically important virus. CYSDV progressively has replaced BPYV as the predominant virus infecting cucurbits in the Almeria region of southern Spain (5). More recently, CYSDV has been reported in

Corresponding author: Y. Abou-Jawdah

E-mail: abujawyf@aub.edu.lb

Names are necessary to report factually on available data; however, the United States Department of Agriculture (USDA) neither guarantees nor warrants the standard of the product, and the use of the name by USDA implies no approval of the product to the exclusion of others that may also be suitable.

Accepted for publication 20 December 2005.

\section{DOI: 10.1094/PD-90-0645}

This article is in the public domain and not copyrightable. It may be freely reprinted with customary crediting of the source. The American Phytopathological Society, 2006.
Portugal (18), Morocco (6), the United States (14), and Lebanon (1). The host range of CYSDV is restricted to the cucurbits (3), and major symptoms include chlorotic mottling, yellowing, and stunting of cucumber (18) and yellowing and severe stunting of melon (14). Cucumber and melon infected by CYSDV show prominent yellowing on lower leaves 4 to 5 weeks after inoculation. Interveinal mottling appears on the older leaves, coalescing to give a bright yellow color and brittle leaves. Symptoms spread upward but never reach the youngest four to five leaves (1). These symptoms, like those caused by most whitefly-transmitted closteroviruses, are confusing to growers and researchers. Except for leaf thickening and brittleness, symptoms easily can be confused with physiological or nutritional disorders, natural aging, or pesticide toxicity (23).

CYSDV is transmitted in a semipersistent manner by Bemisia tabaci biotype 'B' (B. argentifolii) or biotype ' $\mathrm{Q}$ ' in Portugal and Spain $(2,3)$. In serial daily transfers, CYSDV persisted in the vector for 7 to 9 days with a half-life of $72 \mathrm{~h}$, the longest retention time documented among whitefly-transmitted closteroviruses (23). Control of CYSDV in fieldgrown cucurbits currently is based on chemical treatments for the vector and preventive cultural measures, both with limited success. Melon germ plasm resistant to CYSDV has been reported $(17,19)$; however, there are no reports of CYSDV resistance in cucumber. In this research, we screened cucumber germ plasm for reaction to CYSDV and demonstrated differences in virus titer and symptoms.

\section{MATERIALS AND METHODS}

Cucumber germ plasms. The following 124 cucumber accessions were kindly supplied by the United States Department of Agriculture Plant Introduction (PI) Station in Ames, IA, and the National Seed Storage Laboratory, Fort Collins, CO: PIs 118279, 137853, 137856, 163217, 163223, 164284, 164670, 165509, 167050, 167052, 167389, 169352, 169388, 171602, 171612, 172845, 177363, 177364, 181755, 181910, 181942, 183224, 183231, 193496, 200815, 200818, 205181, 211589, 211728, 211975, 212059, 215589, 220338, 222244, 223841, 226461, 227207, 246930, 249562, 255933, 257487, 263080, 264231, 267086, 267743, 274902, 279807, 281448, 283899, 283901, 285606, 285610, 292012, 293432, 296121, $314425,326598,339245,342950,357830$, $358813,358814,368549,385967,390247$, 390951, 401732, 419041, 419214, 426169, 432860, 432862, 458845, 470254, 481612, 481614, 481617, 502331, 511819, 512336, 525155, 525161, 525162, 525165, 532160, 532162, 534539, 534545, 535881, 540415. 605923, and 92806; Ames accessions $10088,12782,13334,13339,13352$, $13353,15676,18059,19038,19039$, 19218, 19219, 19221, 19222, 19228, 20089, 20146, 20153, 20206, and 3950; and National Seed Storage Laboratory (NSL) accessions 15348, 28178, 28188, 28192, 5714, 5720, 5722, 5731, 5746, 5755, and 665913. The multiple-virusresistant cucumber 'TMG1' (22) and susceptible commercial cvs. Olympic F1 (US Agriseeds, San Luis Obispo, CA), Janette F1 (De Ruiter, Bergschenhoek, Holland), and Al-Hassnaa F1 (Nickerson-Zwaan, Made, Holland) also were included.

Virus source and inoculation. A Lebanese isolate of CYSDV was maintained on melon seedlings of cv. Al-Waha F1 (Harris Moran, Modesto, CA) in insect-proof cages. Plants were sprayed as needed with fungicides (azoxystrobin and fenarimol) to control powdery mildew or insecticidal soap (M-Pede) to control insects. CYSDV infection was confirmed by enzyme-linked immunosorbent assay (ELISA; 12) and reverse-transcriptase polymerase chain reaction (RT-PCR; 1 ).

B. tabaci adults were allowed to lay eggs on broccoli for $48 \mathrm{~h}$. Adults were killed by cypermethrin sprays and the new whitefly colony was considered to be free of CYSDV. Seedlings were sown in plastic trays and inoculated when the first true 
leaf was just expanded. Except for the first trial, adult whiteflies acquired the virus by feeding for 24 to $48 \mathrm{~h}$ on CYSDV-infected melons. An average of 40 to 50 whiteflies per seedling were allowed an inoculationaccess period of at least $48 \mathrm{~h}$, and then they were sprayed with imidacloprid (Confidor). Acquisition and inoculation feedings were performed in insect-proof cages.

Field trials. Three field trials were conducted in plastic greenhouses with insectproof nets, two trials during summer 2003 and 2004 at the Agriculture Research and Education Center (AREC) of the American University of Beirut located in the Beqaa Valley, and one trial during fall 2003 in the coastal area of Lebanon. For all three trials, a completely randomized design was used with two replicates per accession and five to six plants per replicate. Plant spacing was between 2 and 2.2 plants $/ \mathrm{m}^{2}$ and cucumbers were grown on trellises using normal horticultural practices. In the first field trial during August 2003, CYSDV was introduced by collecting a large number of whiteflies from commercial cucumber greenhouses naturally infected by CYSDV and releasing them in a plastic greenhouse, where plants had reached the first- to third-leaf stage. Whiteflies were allowed an inoculation-feeding period of 4 days before spraying with insecticides. The second (fall 2003) and third (summer 2004) trials used accessions from the first trial that showed little to no symptom development or had fewer than six plants due to poor seed germination. Individual plants showing low disease severity indices (DSIs) in the first trial were self pollinated and progenies were evaluated in the third trial.

Disease ratings. Yellowing symptoms were scored weekly over five to eight consecutive weeks. DSIs were recorded as $0=$ no symptoms, $1=$ only slight mosaic with no yellowing, $2=$ three to four leaves with clear symptoms and one leaf with severe yellowing, 3 = five to six leaves showing clear symptoms and two to three leaves with severe yellowing, and $4=$ more than six leaves with clear symptoms and at least four leaves with severe yellowing. During the first trial at 10 days post inoculation, populations of $\mathrm{B}$. tabaci were rated on the top five leaves of all accessions using a scale where $0=$ no whiteflies, $1=$ a low number of whiteflies scattered on most of the leaf, 2

Table 1. Disease severity indices (DSIs) of susceptible checks (Al-Hassnaa, Janette, and Olympic) and selected cucumber accessions after inoculation with Cucurbit yellow stunting disorder virus in the first (summer 2003) and second (fall 2003) trials ${ }^{\mathrm{y}}$

\begin{tabular}{|c|c|c|c|c|c|}
\hline \multirow[b]{3}{*}{$\operatorname{Accession}^{z}$} & \multirow{3}{*}{$\frac{\text { First trial }}{\text { DSI at } 8 \text { WPI }}$} & \multicolumn{4}{|c|}{ Second trial } \\
\hline & & \multirow[b]{2}{*}{ DSI at 8 WPI } & \multicolumn{3}{|c|}{ No. of plants with DSI $\geq 2$ at } \\
\hline & & & 4 WPI & 6 WPI & 8 WPI \\
\hline Al-Hassnaa & $\ldots$ & 2 & $5 / 12$ & $7 / 12$ & $8 / 12$ \\
\hline Janette & $\ldots$ & 4 & $4 / 11$ & $8 / 11$ & $9 / 11$ \\
\hline Olympic & $\ldots$ & 4 & $7 / 12$ & $7 / 12$ & $7 / 12$ \\
\hline Ames 3950 & 3 & 1.4 & $1 / 6$ & $1 / 6$ & $1 / 6$ \\
\hline Ames 13334 & 2 & 2 & $5 / 12$ & $6 / 12$ & $7 / 12$ \\
\hline NSL 5720 & 2 & 2 & $2 / 11$ & $9 / 11$ & $9 / 11$ \\
\hline NSL 5722 & 2 & 1.2 & $1 / 11$ & $3 / 11$ & $3 / 11$ \\
\hline NSL 5731 & 4 & 1.2 & $0 / 5$ & $1 / 5$ & $4 / 5$ \\
\hline NSL 5746 & 2.5 & $\ldots$ & . & & \\
\hline PI 92806 & 3 & 1 & $1 / 13$ & $4 / 13$ & $4 / 13$ \\
\hline PI 118279 & 1.5 & 4 & $2 / 4$ & $2 / 4$ & $4 / 4$ \\
\hline PI 164284 & 2 & 4 & $7 / 12$ & $9 / 12$ & $9 / 12$ \\
\hline PI 177364 & 2 & 1 & $2 / 11$ & $2 / 11$ & $2 / 11$ \\
\hline PI 200815 & 2.5 & 1.3 & $0 / 5$ & $2 / 5$ & $5 / 5$ \\
\hline PI 211589 & 2 & 1 & $1 / 9$ & $2 / 9$ & $4 / 9$ \\
\hline PI 246930 & 3 & 2 & $3 / 12$ & $6 / 12$ & $6 / 9$ \\
\hline PI 249562 & 2 & 2 & $5 / 16$ & $10 / 16$ & $10 / 16$ \\
\hline PI 255933 & 2 & 3 & $2 / 4$ & $2 / 4$ & $3 / 4$ \\
\hline PI 274902 & 3 & 3 & $7 / 12$ & $8 / 12$ & $10 / 12$ \\
\hline PI 279807 & $\ldots$ & 1 & $0 / 4$ & $0 / 4$ & $0 / 4$ \\
\hline PI 283899 & 4 & 2 & $6 / 12$ & $7 / 12$ & $7 / 12$ \\
\hline PI 293432 & 2 & 1 & $2 / 11$ & $3 / 11$ & $4 / 11$ \\
\hline PI 342950 & 4 & 3 & $11 / 11$ & $11 / 11$ & $11 / 11$ \\
\hline PI 357830 & 3 & 2 & $7 / 12$ & $8 / 12$ & $8 / 12$ \\
\hline PI 358814 & 3 & 4 & $3 / 12$ & $9 / 12$ & $12 / 12$ \\
\hline PI 401732 & 3 & 1 & $1 / 12$ & $3 / 12$ & $4 / 12$ \\
\hline PI 432862 & 3 & 3 & $2 / 12$ & $10 / 12$ & $11 / 12$ \\
\hline PI 511819 & 2 & 4 & $8 / 12$ & $10 / 12$ & $10 / 12$ \\
\hline PI 512336 & 4 & 3 & $12 / 12$ & $12 / 12$ & $12 / 12$ \\
\hline PI 532162 & 3 & 2 & $2 / 12$ & $5 / 12$ & $5 / 12$ \\
\hline PI 605923 & 2 & 1.3 & $2 / 9$ & $2 / 9$ & $3 / 9$ \\
\hline
\end{tabular}

${ }^{\mathrm{y}}$ DSI rated as follows: $0=$ no symptoms; $1=$ only slight mosaic, no real yellowing; $2=$ only three to four leaves infected (one leaf shows yellowing); 3 = only five to six leaves infected (two or three leaves show yellowing); and $4=$ more than six leaves infected (four leaves and more show yellowing). WPI = weeks post inoculation and $\ldots=$ not tested due to unavailability of seed at the beginning of the trial.

${ }^{\mathrm{z}}$ Bold letters designate the most promising tolerant accessions.

$=$ whiteflies covering half of the leaf, and 3 $=$ whiteflies covering the whole leaf.

CYSDV detection and relative concentrations in infected plants. Tissue blot immunoassay (TBIA) was used to detect CYSDV infection (12) and RT-PCR was used occasionally to confirm infection by CYSDV (1). Relative virus concentrations in randomly selected tolerant and susceptible accessions were evaluated in the second trial using three types of serological assays. Three leaf samples were collected randomly from three different plants of each tolerant and susceptible accession: three just-opened leaves from the top, three of the middle leaves, and three from the bottom leaves, for a total of nine leaves per accession. TBIA, dot blot immunoassay (DBIA), and indirect ELISA were performed as described earlier (12). The DBIA protocol was modified in that leaf samples (leaf midribs) were homogenized $(1: 20 \mathrm{wt} / \mathrm{vol})$ in TBST (Tris-buffer saline + $0.1 \%$ Tween $20, \mathrm{pH} 8,+0.1 \%$ sodium sulfite). A wet, positively charged Nylon membrane (Amersham Biosciences, Little Chalfont, Bucks, UK) was placed in a Biodot microfiltration apparatus according to the manufacturer's instructions (Bio-Rad Laboratories, Hercules, CA) and rinsed with $100 \mu$ of TBST buffer/well. Sample extracts $(6 \mu \mathrm{l}$ of each leaf extract $+44 \mu \mathrm{l}$ of TBST) were applied under vacuum. Following this step, the same protocol was used as described for TBIA, except that the colorimetric detection was replaced by chemiluminescent detection using CDPstar as described by the manufacturer (Amersham Biosciences). The scanned Xray films of the membranes were computer analyzed using the Labworks software (Ultra-Violet Products Ltd., Cambridge, UK) to quantify the intensity of the signals, considering the signal of the healthy control as background reference.

Leaf extracts from two accessions showing typical CYSDV symptoms were used as positive controls. Twofold serial dilutions of leaf extracts from the positive controls from 1:40 to 1:640 were used for ELISA and plotted against their corresponding absorbance readings at $405 \mathrm{~nm}$ $\left(A_{405}\right)$. Absorbance was monitored with Multiskan Ascent, Thermo-Labsystems, Joensuu, Finland. Predicted $A_{405}$ values from regression of absorbance on dilution in positive controls were compared with $A_{405}$ readings from tolerant and susceptible accessions.

Statistical analysis. All statistical analyses were conducted using SPSS 10.0 (completely randomized experimental design) and, when means were significantly different, mean separations were calculated using the least significant difference (LSD) test with significance at $P=0.05$.

\section{RESULTS}

Screening for reaction to CYSDV. In the first field trial of 124 cucumber acces- 
sions, 12 accessions (PIs 118279, 164284, 177364, 211589, 249562, 255933, 293432, 511819, and 605923; Ames 13334; and NSL 5720 and NSL 5722) showed DSIs between 1 and 2 with delayed development of symptoms (Table 1), whereas all other accessions had DSIs greater than 2 or 3 . There was no correlation between level of whitefly infestation and disease severity (data not presented). TBIA and RT-PCR of

Table 2. Disease severity indices (DSIs) of susceptible checks (Al-Hassnaa, Janette, and Olympic) and cucumber accessions after inoculation with Cucurbit yellow stunting disorder virus in the third trial (summer 2004) at 10 $\mathrm{WPI}^{\mathrm{x}}$

\begin{tabular}{llc}
\hline Accession $^{y}$ & $\begin{array}{c}\text { Average } \\
\text { DSI }\end{array}$ & $\begin{array}{c}\text { No. of plants with } \\
\text { DSI }>\text { 3 }\end{array}$ \\
\hline Al-Hassnaa & 3.5 & $9 / 12$ \\
Janette & 3.4 & $6 / 11$ \\
Olympic & 3.4 & $7 / 11$ \\
Ames 3950 & 3.9 & $12 / 12$ \\
Ames 13334 & 2.3 & $0 / 10$ \\
Ames 13334 & 1.3 & $0 / 20$ \\
NSL 5722 & 3.4 & $9 / 12$ \\
NSL 5746 & 2.4 & $0 / 20$ \\
PI 92806 & 3.4 & $8 / 12$ \\
PI 118279 & 3.7 & $9 / 12$ \\
PI 177364 & 3 & $2 / 12$ \\
PI 177364 & 3.3 & $12 / 19$ \\
PI 211589 & 3.3 & $8 / 12$ \\
PI 211589 & 2.9 & $1 / 20$ \\
PI 274902 & 3.8 & $12 / 12$ \\
PI 279807 & 2.7 & $1 / 12$ \\
PI 293432 & 2 & $0 / 12$ \\
PI 293432 & 1.5 & $0 / 20$ \\
PI 401732 & 3.5 & $9 / 11$ \\
PI 511819 & 3.8 & $11 / 11$ \\
PI 605923 & 1.9 & $0 / 10$ \\
\hline
\end{tabular}

${ }^{x}$ DSI rated as follows: $0=$ no symptoms; $1=$ only slight mosaic, no real yellowing; $2=$ only three to four leaves infected (one leaf shows yellowing); $3=$ only five to six leaves infected (two or three leaves show yellowing); and $4=$ more than six leaves infected (four leaves and more show yellowing). WPI $=$ weeks post inoculation.

${ }^{y}$ Bold letters designate the most promising tolerant accessions.

${ }^{\mathrm{z}}$ Selfed progenies from cucumber accessions. leaf samples showed that all accessions were infected by CYSDV; therefore, accessions with lower DSIs did not express severe symptoms even though the virus was present. These accessions will be referred to as tolerant to CYSDV.

The second trial was conducted in the Damour coastal area in November 2003 and included 28 accessions scored as tolerant or susceptible in the first trial (Table 1). Susceptible accessions showed clear symptoms 4 weeks post inoculation (WPI) and had final DSIs between 3 and 4 at 8 WPI. The incidence of plants with DSIs of 2 or more (DSI $\geq 2$ ) ranged between 60 and $100 \%$ (Table 1) on susceptible accessions. The average DSI at 8 WPI of the selected tolerant accessions (PIs 177364, 211589, 293432, 605923, 279807, 401732, and 92806; Ames 13334 and Ames 3950; and NSL 5722) ranged between 1 and 2 . Over60 \% of plants developed none to mild symptoms (Table 1). The lower mean DSI of the tolerant accessions correlated with delayed symptom appearance at 6 to 8 WPI, compared with 28 days in susceptible controls. In the first two experiments, PIs 293432 and 605923 and Ames 13334 were the most promising, followed by accessions PIs 177364, 211589, and 279807, with DSIs ranging between 1 and 2 (Table 1).

Conditions in the third trial greatly favored disease development. Between 57 and $100 \%$ of plants from the susceptible cvs. Al-Hasnaa, Olympic, and Janette, as well as accessions PIs 118279, 211589, 274902, 401732, and 511819; Ames 3950; and NSL 5722 developed severe yellowing (DSI > 3). No plants in accessions PI 293432, PI 605923, and Ames 13334 , as well as self-pollinated progenies from accessions PI 293432, Ames 13334, and NSL 5746, showed severe yellowing symptoms (Table 2). Relatively few plants from accessions PIs 279807 and 177364 and selfed progenies from PI 211589 showed yellowing symptoms with DSI $>3$.
Comparison of relative virus concentrations. TBIA was performed 16 and 18 WPI in the second trial. For both time periods, the middle leaves showed the most consistent detection of the virus, with more intense precipitation in areas corresponding to the vascular tissue, whereas variations were observed in the upper and lower leaves (Table 3). We completed quantitative tests using DBIA and ELISA. These serological tests detect the CYSDV coat protein concentration, which may be positively correlated with relative virus concentration. In preliminary tests, the middle leaves of susceptible accessions had the highest relative virus concentrations, followed by the lower leaves, whereas the upper leaves showed considerable variation in relative virus concentrations. Therefore, the quantitative tests were performed only with extracts from the middle and lower leaves. For DBIA at 18 WPI, integrated optical density (IOD) readings of the viral antigen in the middle leaf extracts for four susceptible accessions (PI 274902, PI 511819, Olympic, and Janette) ranged between 65 and 214. The respective IOD readings were less than 1.2 for five tolerant accessions (PIs 177364 and 211589, Ames 13334, PI 605923, and Ames 3950), revealing lower virus concentrations than in susceptible accessions (Table 4). Differences also were observed for relative virus concentrations in lower leaves, ranging between 12.8 and 36.7 for the susceptible accessions and less than 0.8 in the five most tolerant ones (data not shown).

ELISA readings $\left(A_{405}\right)$ at 18 WPI revealed that virus titers in the tolerant accessions PIs 177364, 211589, and 605923, Ames 13334, and Ames 3950 were significantly lower than in the susceptible controls (Table 5). Serial dilutions of leaf extracts from 'Janette' and 'Olympic' showed linear relationships $\left(R^{2}=0.92\right.$ and 0.98 , respectively) between $A_{405}$ readings and dilutions from $1 / 40$ to $1 / 640$. Comparison of $A_{405}$ values from regression of absorb-

Table 3. Detection of Cucurbit yellow stunting disorder virus in top, middle, and bottom leaves of selected tolerant and susceptible cucumber accessions as determined by tissue blot immunoassay at 16 and 18 weeks post inoculation (WPI) ${ }^{\mathrm{x}}$

\begin{tabular}{|c|c|c|c|c|c|c|c|}
\hline \multirow[b]{2}{*}{ Accession $^{y}$} & \multirow[b]{2}{*}{ Phenotype $^{\mathrm{z}}$} & \multicolumn{3}{|c|}{ Leaves at 16 WPI } & \multicolumn{3}{|c|}{ Leaves at 18 WPI } \\
\hline & & Top \pm SD & Middle \pm SD & Bottom \pm SD & Top \pm SD & Middle \pm SD & Bottom \pm SD \\
\hline Olympic & $S$ & $1 \pm 1$ & $4 \pm 0$ & $3 \pm 0$ & $2 \pm 0.6$ & $2.3 \pm 0$ & $2.3 \pm 1.7$ \\
\hline Janette & $\mathrm{S}$ & $0.7 \pm 0.6$ & $4 \pm 0$ & $1.5 \pm 2.1$ & $1.7 \pm 0.6$ & $4 \pm 0$ & $2 \pm 0.6$ \\
\hline Ames 3950 & $\mathrm{~T}$ & $0 \pm 0$ & $0 \pm 0$ & $0 \pm 0$ & $0 \pm 0$ & $0 \pm 0$ & $0 \pm 0$ \\
\hline Ames 13334 & $\mathrm{~T}$ & $0 \pm 0$ & $0 \pm 0$ & $0 \pm 0$ & $0 \pm 0$ & $0 \pm 0$ & $0 \pm 0$ \\
\hline NSL 5722 & $(\mathrm{~T})$ & $1 \pm 1$ & $2.3 \pm 2$ & $0.3 \pm 0.7$ & $1.3 \pm 1.1$ & $2.7 \pm 2.3$ & $1.3 \pm 2.3$ \\
\hline PI 177364 & $\mathrm{~T}$ & $0 \pm 0$ & $0 \pm 0$ & $0 \pm 0$ & $0 \pm 0$ & $0 \pm 0$ & $0 \pm 0$ \\
\hline PI 211589 & $\mathrm{~T}$ & $0 \pm 0$ & $0 \pm 0$ & $0 \pm 0$ & $0.7 \pm 1.1$ & $0 \pm 0$ & $0 \pm 0$ \\
\hline PI 401732 & $(\mathrm{~T})$ & $0 \pm 0$ & $0.3 \pm 0.6$ & $0 \pm 0$ & $0.5 \pm 0.6$ & $0 \pm 0$ & $1.3 \pm 2.3$ \\
\hline PI 511819 & $\mathrm{~S}$ & $0.5 \pm 0.6$ & $3.3 \pm 0.6$ & $0.5 \pm 0.7$ & $2 \pm 0$ & $3.7 \pm 0.6$ & $2 \pm 1.7$ \\
\hline PI 605923 & $\mathrm{~T}$ & $0.7 \pm 1.1$ & $1.3 \pm 1.1$ & $1 \pm 1.4$ & $2 \pm 2$ & $0 \pm 0$ & $0.3 \pm 0.6$ \\
\hline Negative control & $\ldots$ & $0 \pm 0$ & $0 \pm 0$ & $0 \pm 0$ & $0 \pm 0$ & $0 \pm 0$ & $0 \pm 0$ \\
\hline
\end{tabular}

${ }^{\mathrm{x}}$ Readings according to the following scale: $0=$ no precipitate detected, $1=$ precipitate just visible, $2=$ precipitate obvious but not strong, $3=$ strong precipitate, and $4=$ very strong precipitate; mean \pm standard deviation $(\mathrm{SD})$ of three readings.

${ }^{\text {y }} \mathrm{S}=$ susceptible accession or cultivar, $\mathrm{T}=$ tolerant accession, and $(\mathrm{T})=$ phenotype of most plants is tolerance but some plants showed severe symptoms.

${ }^{\mathrm{z}}$ Bold letters designate the most promising tolerant accessions. 
ance on dilution in positive controls with $A_{405}$ readings from tolerant and susceptible accessions (Table 5) showed that the tolerant accessions PI 211589, PI 605923, PI 177364, Ames 13334, and Ames 3950 had relative virus titers much lower than those of susceptible accessions. Similar observations on relative virus concentrations between tolerant and susceptible controls were observed from ELISA analyses of the bottom leaves (data not shown). Both the ELISA and DBIA tests confirmed that CYSDV relative concentrations in the tolerant accessions PI 177364, PI 211589, PI 605923, Ames 13334, and Ames 3950 were significantly less than those of the susceptible accessions.

\section{DISCUSSION}

CYSDV causes severe losses in the Mediterranean region, and its rapid spread makes it one of the most important viruses infecting the cucurbits (16). In Lebanon, the incidence of CYSDV may reach $100 \%$ in summer production in plastic greenhouses without insect-proof screens, with yield reductions of 40 to $50 \%$ (1). We evaluated 124 cucumber accessions for reaction to CYSDV in three field trials using viruliferous whiteflies under controlled inoculation conditions. None of the cucumber accessions showed immunity, unlike that reported for melon (17). However consistently lower DSIs were observed in accessions PIs 293432 and 605923 and Ames 13334 in all three field trials. Other promising accessions with relatively low DSIs included PI 177364, PI 279807, and self-pollinated progenies from PI 211589 and NSL 5746 (Tables 1 and 2).

Table 4. Integrated optical density (IOD) readings at 18 weeks post inoculation revealing relative Cucurbit yellow stunting disorder virus concentrations in middle leaves of selected tolerant and susceptible cucumber accessions using dot blot immunoassay chemiluminescent detection

\begin{tabular}{lcc}
\hline Accession $^{\mathbf{x}}$ & Phenotype $^{\mathbf{y}}$ & IOD $^{\mathbf{z}}$ \\
\hline Janette & $\mathrm{S}$ & $65.1 \pm 59.5 \mathrm{ac}$ \\
Olympic & $\mathrm{S}$ & $214.3 \pm 93.3 \mathrm{~b}$ \\
Ames 3950 & $\mathrm{T}$ & $1.2 \pm 1.4 \mathrm{a}$ \\
Ames 13334 & $\mathrm{T}$ & $0.1 \pm 0.2 \mathrm{a}$ \\
NSL 5722 & $(\mathrm{T})$ & $139.5 \pm 192.6 \mathrm{bc}$ \\
PI 177364 & $\mathrm{T}$ & $0.5 \pm 0.4 \mathrm{a}$ \\
PI 211589 & $\mathrm{T}$ & $0.3 \pm 0.1 \mathrm{a}$ \\
PI 274902 & $\mathrm{S}$ & $87.6 \pm 76.7 \mathrm{ac}$ \\
PI 401732 & $(\mathrm{T})$ & $95.7 \pm 165.7 \mathrm{ac}$ \\
PI 511819 & $\mathrm{S}$ & $128.9 \pm 14.8 \mathrm{bc}$ \\
PI 605923 & $\mathrm{T}$ & $1 \pm 0.6 \mathrm{a}$ \\
\hline
\end{tabular}

${ }^{x}$ Bold letters designate the most promising tolerant accessions.

y $\mathrm{S}=$ susceptible accession or cultivar, $\mathrm{T}=$ tolerant accession, and $(\mathrm{T})=$ phenotype of most plants is tolerance but some plants showed severe symptoms.

${ }^{\mathrm{z}}$ Mean \pm standard deviation of three readings from three different seedlings. Means followed by same letter were not significantly different at $P \leq 0.05$ using the least significant difference test.
The most severe symptoms were observed in the third trial after seedlings were subjected to heavy inoculum pressure with high summer temperatures. Because these conditions seldom occur in production fields, these accessions may perform better when inoculation occurs at a later growth stage or with lower inoculum. The whitefly density on inoculated leaves was similar between accessions with and without symptoms, indicating that tolerance to whitefly is not a major factor in the development of CYSDV symptoms on cucumber.

Serological assays showed that CYSDV is unevenly distributed within the cucumber plant and that middle leaves are better than the top and bottom leaves to compare relative virus concentrations in the plant. Similar results were reported for CYSDV in melon (19). In this respect, progression of CYSDV infections differed from other viruses in which younger leaves had the higher virus titers early after inoculation (13), and was similar to other closteroviruses in which older leaves had higher virus titers $(15,20)$. Both DBIA and ELISA readings at 18 WPI revealed that accessions PI 605923, Ames 3950, Ames 13334, PI 177364, and PI 211589 had lower DSIs and significantly lower virus concentrations than susceptible accessions. The large standard deviations observed in some accessions (Tables 4 and 5) may be due to escapes, even under high inoculum pressure (5). However, accessions with lower DSIs were not immune to CYSDV. Rather, virus concentrations were too low to be

Table 5. Mean absorbance using indirect enzyme-linked immunosorbent assay for Cucurbit yellow stunting disorder virus in extracts from middle leaves of 11 selected cucumber accessions at 18 weeks post inoculation ${ }^{\mathrm{w}}$

\begin{tabular}{lcc}
\hline Accession $^{\mathbf{x}}$ & Phenotype $^{\mathbf{y}}$ & $\boldsymbol{A}_{\mathbf{4 0 5}}$ readings $^{\mathbf{z}}$ \\
\hline Janette & $\mathrm{S}$ & $2.2 \pm 0.4 \mathrm{~b}$ \\
Olympic & $\mathrm{S}$ & $2.4 \pm 0.3 \mathrm{~b}$ \\
Ames 3950 & $\mathrm{T}$ & $0.2 \pm 0.2 \mathrm{a}$ \\
Ames 13334 & $\mathrm{T}$ & $0.2 \pm 0.3 \mathrm{a}$ \\
NSL 5722 & $(\mathrm{T})$ & $1.7 \pm 1.4 \mathrm{bc}$ \\
PI 177364 & $\mathrm{T}$ & $0.4 \pm 0.1 \mathrm{a}$ \\
PI 211589 & $\mathrm{T}$ & $0.3 \pm 0.1 \mathrm{a}$ \\
PI 274902 & $\mathrm{S}$ & $1.8 \pm 1.2 \mathrm{bc}$ \\
PI 401732 & $(\mathrm{T})$ & $1.0 \pm 1.4 \mathrm{ac}$ \\
PI 511819 & $\mathrm{S}$ & $2.0 \pm 0.1 \mathrm{bc}$ \\
PI 605923 & $\mathrm{T}$ & $0.3 \pm 0.3 \mathrm{a}$ \\
Negative control & $\ldots$ & $0.2 \pm 0.2 \mathrm{a}$ \\
\hline
\end{tabular}

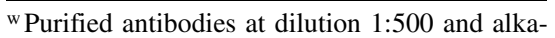
line phosphatase-conjugated goat anti-rabbit immunoglobulin $\mathrm{G}$ at dilution 1:10,000.

${ }^{x}$ Bold letters designate the most promising tolerant accessions.

${ }^{\text {y }} \mathrm{S}=$ susceptible accession or cultivar, $\mathrm{T}=$ tolerant accession, and $(\mathrm{T})=$ phenotype of most plants is tolerance but some plants showed severe symptoms.

${ }^{\mathrm{z}}$ Absorbance readings at $405 \mathrm{~nm}\left(A_{405}\right)$; means \pm standard deviation are from three readings from three different seedlings. Means followed by same letters are not significantly different at $P \leq 0.05$ using the least significant difference test. detected by ELISA. The virus was revealed by DBIA, which is a more sensitive detection method.

Virus resistance can be defined as a reduction in symptoms associated with reduced virus concentrations, whereas tolerance often is defined as a reduction of symptoms with slight or no reduction in virus concentrations $(10,21)$. Germ plasms with limited or no virus replication in the inoculated leaves are preferred to reduce the spread of CYSDV from resistant plants to nearby nonresistant cucurbits. Resistance to CYSDV in the melon 'TGR-1551' was controlled by a single dominant gene (17) which may restrict virus movement in the vascular system of the plants or prevent high levels of virus accumulation (19). Cucumber accessions PI 211589, PI 605923, and Ames 13334 showed tolerance to CYSDV because they developed less severe symptoms in three different tests, and accumulated lower virus titers compared with susceptible accessions. Accessions PIs 177364, 279807, and 293432 and NSL 5746 also may be promising sources of tolerance under moderate disease pressure. In the future, studies should address the mechanism and inheritance of tolerance in cucumber to CYSDV.

\section{ACKNOWLEDGMENTS}

This research was funded partially by the Pickle Seed Research Foundation and United States Department of Agriculture Specific Cooperative Agreement 58-3655-3-F105 with the American University of Beruit (AUB). Seeds were kindly provided by the NCRPIS (North Central Regional Plant Introduction Station) and the United States National Plant Germplasms System (NPGS). The DBIA tests were performed at the Central Research Science Laboratory (CRSL) at AUB.

\section{LITERATURE CITED}

1. Abou-Jawdah, Y., Sobh, H., Fayad, A., Lecoq, H., Delecolle, B., and Trad-Ferre, J. 2000. $\mathrm{Cu}$ curbit yellow stunting disorder virus- a new threat to cucurbits in Lebanon. J. Plant Pathol. 82(1):55-60.

2. Anonymous. 1997. Bemisia tabaci. Pages 121127 in: Quarantine Pests for Europe, 2nd ed. I. M. Smith, D. G. McNamara, P. R. Scott, and M. Holderness, eds. CAB International, Wallingford, UK

3. Berdiales, B., Bernal, J. J., Saez, E., Woudt, B., Beitia, F., and Rodriguez-Cerezo, E. 1999. Occurrence of Cucurbit yellow stunting disorder virus (CYSDV) and Beet pseudo-yellow virus in cucurbit crops in Spain and transmission of CYSDV by two biotypes of Bemisia tabaci. Eur. J. Plant Pathol. 105:211-215.

4. Brown, J. K., and Nelson, M. R. 1986. Whitefly-borne viruses of melons and lettuce in Arizona. Phytopathology 76:236-239.

5. Célix, A., Lopez-Sése, A., Almarza, N., Gomez-Guillamon, M. L., and Rodriguez-Cerezo, E. 1996. Characterization of Cucurbit yellow stunting disorder virus, a Bemisia tabacitransmitted Closterovirus. Phytopathology 86:1370-1376.

6. Desbiez, C., Lecoq, H., Aboulama, S., and Peterschmitt, M. 2000. First report of Cucurbit yellow stunting disorder virus in Morocco. Plant Dis. 84(5):596.

7. Duffus, J. E. 1965. Beet pseudo-yellows virus, transmitted by the greenhouse whitefly (Trialeurodes vaporariorum). Phytopathology 55:450-453. 
8. Duffus, J. E. 1995. Whitefly-transmitted yellowing viruses of the Cucurbitaceae. Pages 1216 in: Cucurbitaceae 94: Evaluation and Enhancement of Cucurbit Germplasm. G. E. Lester and J. R. Dunlap, eds. Gateway Printing, South Padre Island, TX.

9. Duffus, J. E., Larsen, R. C., and Liu, H. Y. 1986. Lettuce infectious yellows virus-a new type of whitefly-transmitted virus. Phytopathology 76:97-100.

10. Fraser, R. S. S. 1990. The genetics of resistance to plant viruses. Annu. Rev. Phytopathol. 28:179-200.

11. Hassan, A. A., and Duffus, J. E. 1991. A review of a yellowing and stunting disorder of cucurbits in the United Arab Emirates. Emirates J. Agric. Sci. 2:1-16.

12. Hourani, H., and Abou-Jawdah, Y. 2003. Immunodiagnosis of Cucurbit yellow stunting disorder virus using polyclonal antibodies developed against recombinant coat protein. J. Plant Pathol. 85(3):197-204.

13. Hull, R. 2002. Matthew's Plant Virology. Academic Press, San Diego, CA.
14. Kao, J., Jia, L., Tian, T., Rubio, L., and Falk, B. W. 2000. First report of Cucurbit yellow stunting disorder virus (genus Crinivirus) in North America. Plant Dis. 84(1):101.

15. Kreuze, J. F, Savenkov, E. I., and Valkonen, J. P. T. 2002 .Complete genome sequence and analyses of the subgenomic RNAs of Sweet potato chlorotic stunt virus reveal several new features for the genus Crinivirus. J. Virol. 76:9260-9270

16. Lecoq, H., Wisler, G., and Pitrat, M. 1998. Cucurbit viruses: The classic and the emerging. Pages 126-142 in: Cucurbitaceae 98 Evaluation and Enhancement of Cucurbit Germplasm. J. D. McCreight, ed. American Society for Horticultural Sciences, Alexandria, VA.

17. López-Sése, A. I., and Gomez-Guillamon, M. L. 2000. Resistance to Cucurbit yellow stunting disorder virus (CYSDV) in Cucumis melo L. Hortic. Sci. 35(1):110-113.

18. Louro, D., Vicente, M., Veira, A. M., Accoto, G. P., and Nolasco, G. 2000. Cucurbit yellow stunting disorder virus (genus Crinivirus) as- sociated with the yellowing disease of cucurbit crops in Portugal. Plant Dis. 84(10):1156.

19. Marco, C. F., Aguilar, J. M., Abad, J., GomezGuillamon, M. L., and Aranda, M. A. 2003. Melon resistance to Cucurbit yellow stunting disorder virus is characterized by reduced virus accumulation. Phytopathology 93:844-852.

20. Monis, J., and Bestwick, R. K. 1996. Detection and localization of Grapevine leafroll associ ated closteroviruses in greenhouse and tissue culture grown plants. An. J. Enol. Vitic. 47:199-205.

21. Valkonen, J. P. T. 2002. Natural resistance to viruses. Pages 367-388 in: Plant Viruses as Molecular Pathogens. J. A. Khan and J. Dijkstra, eds. Food Products Press, Binghanton, NY.

22. Wai, T., Staub, J. E., and Grumet, R. 1997. Linkage analysis of potyvirus resistance alleles in cucumber. J. Hered. 88:454-458.

23. Wisler, G. C., Duffus, J. E., Liu, H. Y., and Li, R. H. 1998. Ecology and epidemiology of whitefly-transmitted closteroviruses. Plant Dis. 82(3):270-280 